Jurnal Interpretasi Hukum | ISSN: 2746-5047

Vol. 2, No. 3-Desember 2021, Hal. 646-650| Tersedia online di https://www.ejournal.warmadewa.ac.id/index.php/juinhum DOI: https://doi.org/10.22225/juinhum.2.3.4166.646-650

\title{
PERLINDUNGAN HUKUM BAGI PARA PIHAK DALAM KONTRAK BISNIS MELALUI E-COMMERCESEBAGAI AKIBAT DARI RESESI EKONOMI
}

\author{
I Putu Setiawan Ivan Baskara, I Nyoman Putu Budiartha, Ni Made Puspasutari Ujianti \\ Fakultas Hukum, Universitas Warmadewa, Denpasar-Bali, Indonesia \\ ivanbaskara32@gmail.com, budiarthaputu59@gmail.com, puspasutariujianti@gmail.com
}

\begin{abstract}
Abstrak
Perkembangan globalisasi yang telah mendunia saat ini, membuat beberapa perubahan dalam sistem perdagangan. E-Commerce atau yang sering disebut dengan transaksi elektronik merupakan suatu kegiatan perdagangan yang dilakukan secara online oleh pelaku usaha dan konsumen dalam melakukan kegiatan perdagangan. Apabila timbul sengketa antara para pihak akibat dari transaksi elektronik, khususnya di Indonesia mengenai transaksi elektronik telah diatur secara khusus di dalam Undang-undang No. 11 Tahun 2008 tentang Informasi dan Transaksi Elektronik guna memberikan perlindungan hukum terhadap para pihak yang bersengketa. Penelitian ini bertujuan untuk mengkaji pengaturan hukum dalam transaksi jual beli melalui $E$ Commerce dan mengungkapkan perlindungan hukum bagi para pihak dalam E-Commerce sebagai akibat dari resesi ekonomi. Dalam mengolah data penelitian menggunakan penelitian hukum normatif dengan pendekatan Perundang-undangan. Sumber data yang digunakan adalah data hukum primer dan sekunder yang diperoleh melalui studi kepustakaan. Setelah data penelitian terkumpul, tahap terakhir adalah mengolah data denagn metode kualitatif deskriptif. Hasil penelitian ini menunjukkan bahwa perlindungan hukum yang diberikan terhadap para pihak yang bersengketa akibat dari kontrak bisnis yang dilakukan menggunakan sistem transaksi elektronik yaitu dengan cara mengajukan gugatan di pengadilan niaga dengan melampirkan bukti kontrak bisnis elektronik yang telah disepakati oleh para pihak, bukti elektronik merupakan bukti yang sah sebagaimana diatur di dalam Undang-undang No. 11 Tahun 2008 tentang Informasi dan Transaksi Elektronik yang bertujuan untuk memberikan perlindungan terhadap para pihak yang bersengketa di tengah resesi ekonomi yang melanda hampir seluruh negara di dunia saat ini.
\end{abstract}

Kata Kunci: Perlindungan Hukum, Para Pihak, Transaksi Elektronik

\begin{abstract}
The development of globalization which has become global today, has made several changes in the trading system. E-Commerce or what is often referred to as electronic transaction is a trading activity carried out online by business actors and consumers in conducting trading activities. If a dispute arises between the partie $s$ as a result of electronic transactions, especially in Indonesia regarding electronic transactions, it has been specifically regulated in Law no. 11 of 2008 concerning Information and Electronic Transactions in order to provide legal protection to the disputing parties. This study aims to examine the legal arrangements in buying and selling transactions through E-Commerce and revealing legal protection for parties in E-Commerce as a result of the economic recession. In processing research data using normative legal research with a Legislative approach. Sources of data used are primary and secondary legal data obtained through literature study. After the research data has been collected, the last stage is to process the data with descriptive qualitative methods. The results of this study indicate that the legal protection provided to the disputing parties as a result of a business contract carried out using an electronic transaction system is by filing a lawsuit in a commercial court by attaching evidence of an electronic business contract that has been agreed upon by the parties. legal as regulated in Law no. 11 of 2008 concerning Information and Electronic Transactions, which aims to provide protection to the disputing parties in the midst of an economic recession that has hit almost all countries in the world today.
\end{abstract}

Keywords: Legal Protection, Parties, Electronic Transactions

\section{PENDAHULUAN}

Pada era globalisasi saat ini sangat bereefek pada dalam berbagai segi kehidupan manusia. Kemajuan ini hampir dirasakan oleh berbagai bidang seperti kemajuan pada sistem perdagangan. Sebelumnya setiap aktivitas perdagangan lebih cenderung menggunakan sistem konvensional, yaitu dengan berinteraksi secara langsung antara pelaku bisnis atau pedagang dengan konsumen. Namun seiring 
berkembangnya globalisasi dan kemajuan teknologi yang terjadi saat ini, membuat perubahan terhadap cara perdagangan yang dilakukan secara konvensional yang dialihkan dalam bentuk online menggunakan sarana elektronik. Istilah transaksi elektronik atau yang lebih dikenal dengan $E$ Commerce memberikan banyak kemudahan terhadap para pihak yang terlibat dalam suatu kegiatan bisnis, mulai dari kontrak bisnis yang dilakukan secara elektronik hingga metode pembayaran yang dilakukan secara elektronik.

Saat ini, pengaruh teknologi internet dan media elektronik sudah tidak dapat dipisahkan dari sendi kehidupan masyarakat untuk dapat mengakses suatu informasi. Semakin lama, maka semakin banyak kemunculan media elektronik yang berlomba-lomba untuk menyampaikan informasi dan berita yang terbaru untuk masyarakat dari golongan muda hingga golongan dewasa. Bisa dikatakan bahwa saat ini media internet atau elektronik yang sering diakses dan banyak dikunjungin oleh masyarakat untuk mendapatkan suatu informasi dan berita terbaru, seperti Whatsapp, Line, Youtube, Instagram, Facebook dan lainnya (Yuliana, 2000).

Pada kegiatan transaksi elektronik (E-Commerce) terdapat dua pola transaksi perdagangan yang terjadi yakni bussines to bussines E-Commerce (perdagangan antara pelaku usaha) dan business to consumer E-Commerce (perdagangan antara pelaku usaha dengan konsumen). Pada kegiatan transaksi elektronik ini media elektronik memiliki peranan yang sangat penting dalam kegiatan perdagangan yang dilakukan secara elektronik atau online. Media elektronik merupakan salah satu pengantar para pedagang dan pembeli dalam melakukan transaksi secara online. Transaksi secara elektronik banyak diminati oleh berbagai kalangan masyarakat di seluruh dunia dikarenakan sistemnya yang sangat memberikan kemudahan terhadap sistem perdagangannya dikarenakan antara pelaku usaha dan konsumen tidak perlu melakukan pertemuan yang digantikan dengan cara virtual melalui berbagai aplikasi pertemuan yang dapat dilakukan secara tatap muka menggunakan media internet (Ummah, 2017). Media online yang berkecimpung dalam kegiatan transaksi elektronik atau transaksi digital, hal tersebut memberikan kemudahan terhadap sistem perdagangan yang dilakukan dikarenakan memiliki cakupan yang sangat luas, mengingat transaksi elektronik ini bisa dilakukan oleh para pelaku usaha dan konsumen di seluruh dunia tanpa harus bersusah payah untuk meluangkan waktunya untuk dapat bertemu secara langsung.

Meskipun pada saat melakukan kesepakatan bisnis yang bersifat virtual hal tersebut dapat dikategorikan sebagai tindakan atau perbuatan hukum yang nyata. Secara hukum ruang dalam melakukan transaksi bisnis sangat sulit untuk dilacak keberadaan pihak tersebut sehingga dalam melakukan kontrak bisnis secara elektronik atau digital sangat diperlukan kehati-hatian ketika hendak mengadakan kontrak bisnis, dikarenakan dalam melakukan kontrak bisnis ini memiliki risiko yang sangat tinggi (Nugroho, 2008). Apabila dicermati dari pengertian transaksi elektronik itu sendiri, yang dimaksud dengan transaksi elektronik adalah metode transaksi yang dilakukan tanpa melakukan pertemuan secara langsung ketika melakukan suatu perikatan, selain itu bentuk kontrak bisnis yang dituangkan dalam bentuk transaksi elektronik merupakan bentuk kontrak yang dituangkan dalam bentuk konvensional pada umumnya, yang membedakan dari transaksi elektronik dengan transaksi secara konvensional adalah terletak pada media penuangan isi kontrak yang dilakukan melalui surat elektronik, jika pada transaksi elektronik,isi dari kontrak bisnis yang dilakukan secara elektronik lalu bukti transaksinya dituangkan dalam media cetak (invoice), sedangkan dalam sistem transaksi konvensional, isi dari kontrak tersebut dituangkan secara langsung diatas kertas dengan melakukan pertemuan langsung antara para pihak yang terlibat dalam transaksi bisnis.

Transaksi elektronik tentunya memiliki dampak positif dan dampak negatif dari transaksi elektronik itu sendiri, apabila kita lihat transaksi elektronik melalui sisi positif, maka dapat dilihat bahwa transaksi elektronik atau E-commerce sangat banyak memiliki manfaat dan kegunaan dalam bidang transaksi, yakni mempermudah para pihak dalam menyusun substansi kontrak elektronik yang akan disepakati, selanjutnya adalah sangat menghemat waktu ketika melakukan negosiasi dengan para pihak walaupun terpisah dengan jarak dan waktu, selanjutnya dampak negatif dari transaksi elektronik adalah para pihak dalam melakukan negosiasi tidak melakukan pertemuan secara langsung untuk dapat membahas kemungkinan-kemungkinan yang akan terjadi dalam kerjasama yang dilakukan oleh para pihak (Maulana et al., 2015). Para pihak tidak leluasa untuk menentukan isi kontrak yang akan disepakati oleh para pihak, selain itu di Indonesia transaksi elektronik dalam Kitab Undang-undang Hukum Perdata tidak disebutkan bahwa bentuk perikatan atau kerjasama yang dilakukan oleh para 
pihak dapat dilakukan dalam bentuk elektronik, sehingga pemerintah menerbitkan UU ITE sebagai dasar hukum untuk mengatur sanksi atau pelanggaran mengenai transaksi elektronik yang terjadi seiring perkembangan zaman apabila dikemudian hari menuai suatu permasalahan diantara para pihak.

Terkait masalah transaksi melaui media online telah banyak diteliti oleh penelitian terdahulu, namun sampai saat ini kasus ini masih terus terjadi terutama dalam kalangan bisnis. Wulandari, (2018) selain memberi kemudahan dalam kegiatan transaksi perdagangan juga memberi peluang terjadinya penipuan baik konsumen maupun maupun pelaku usaha, menghindari hal ini maka pemerintah harus memberikan perlindungan hukum terhadap korban. Penelitian lain mengungkapkan karena adanya transaksi elektronik dalam bidang perdangan maka banyak kasus penipuan dan tidak sedikit terjadi konflik, karena kasus ini dianggap serius maka pemerintah membuat UU ITE yang mengatur tentang transaksi elektronik (Putra, 2014) \& (Rongiyati, 2019). Berdasarkan penjabaran permasalahan yang telah dipaparkan di awal dan pernyataan penelitian tetrdahulu maka penelitian ini dilakukan dengan tujuan untuk mengkaji pengaturan hukum dalam transaksi jual beli melalui $E$ Commerce dan mengungkapkan perlindungan hukum bagi para pihak dalam E-Commerce sebagai akibat dari resesi ekonomi.

\section{METODE PENELITIAN}

Penelitian yang digunakan adalah penelitian hukum normatif yaitu penelitian yang menggunakan pengkajian masalah melalui pendekatan peraturan Perundang-undangan yang berlaku atau hukum positif di Indonesia, sehingga pengkajian masalah melalui pendekatan perundang-undangan. Undangundang menjadi sumber bahan hukum utama dalam. Selanjutnya sumber bahan hukum sekunder yang digunakan adalah dengan menggunakan pendekatan pengkajian melalui buku-buku akademik sebagai penunjang peneliti dalam memecahkan masalah-masalah yang dihadapi, sedangkan sumber bahan hukum tersier yang digunakan dalam pemecahan masalah dalam penulisan jurnal hukum ini adalah dengan menggunakan kamus-kamus hukum, jurnal yang memiliki kaitan erat dengan permasalahan yang dihadapi penulis dalam mengkaji dan memecahkan suatu permasalah yang dihadapi ketika melakukan penelitian ini (Hartono, 1994). Teknik pengumpulan sumber bahan hukum yang digunakan adalah teknik studi pustaka guna membantu memecahkan masalah-masalah yang dihadapi ketika melakukan penelitian ini, langkah-langkah yang dilakukan ketika mengumpulkan sumber bahan hukum dalam penelitian ini yakni terlebih dahulu mencari sumber bahan hukum primer meliputi peraturan Perundang-undangan, kamus penunjang, selanjutnya melakukan filterisasi dalam memilah-milah sumber bahan hukum yang sudah terkumpul tadi, apabila sudah terkumpul maka digunakan teknik elaborasi yakni menggabungkan sumber bahan hukum primer,sekunder dan tersier tadi dengan logika deduktif dan induktif (Sunggono, 2003).

\section{HASIL DAN PEMBAHASAN}

\section{Pengaturan Hukum Terhadap Transaksi Elektronik dalam Peraturan Perundang-undangan}

Indonesia merupakan suatu Negara Hukum yang mana segala tingkah laku atau perbuatan yang dilakukan oleh manusia diatur oleh hukum (Azhari, 2012). Hukum harus sungguh-sungguh difungsikan agar pembangunan ekonomi benar-benar berjalan sesuai dengan garis kebijaksanaan yang diamanatkan oleh Undang-undang Dasar 1945. Hukum seharusnya berdiri di depan pembangunan, sebab jika tidak demikian persoalan ketidakpastian hukum akan selalu muncul mengiringi perkembangan perekonomian (Gede \& Putu, 2018). Dalam menghadapi era teknologi informasi yang semakin cepat tanpa dibatasi waktu dan wilayah negara, hukum di Indonesia sangat jauh tertinggal. Banyak permasalahan-permasalahan yang belum terpecahkan melalui instrumen hukum ini.

Pengembangan sektor hukum diharapkan mampu memberikan kontribusi terhadap percepatan pembangunan perekonomian. Padahal kondisi umum di Indonesia belum mendukung kesiapan Indonesia dalam menghadapi persaingan global. Saat ini internet merupakan penyumbang angka kejahatan yang sangat signifikan, kemunculan kejahatan yang terjadi di internet sangat beragam jenis, mulai dari penipuan, penyebaran berita bohong dan berbagai kejahatan lainnya, tentunya hal tersebut sangat perlu mendapatkan perhatian khusus dari pemerintah guna menanggulangi hal tersebut, saat ini kejahatan yang terjadi di dunia internet sering disebut sebagai cyber crime atau kejahatan yang dilakukan melalui dunia maya, kejahatan di internet dapat dilakukan oleh berbagai orang di seluruh 
dunia. Cybercrime atau kejahatan yang terjadi di dunia maya merupakan kejahatan yang tergolong baru apabila dibandingkan dengan kejahatan yang tidak dilakukan pada dunia maya, kejahatan dunia maya makin berkembang pesat saat ini, seiring perkembangan teknologi internet yang terjadi saat in (Hadjon, 1987).

Pengaturan mengenai transaksi elektronik di Indonesia secara khusus telah diatur di dalam Undang-undang Nomor 11 Tahun 2008 tentang Informasi dan Transaksi Elektronik khususnya di dalam Pasal 20 ayat (2) UU No.11 Tahun 2008 tentang Transaksi Elektronik, dalam pasal ini disebutkan bahwa setiap transaksi elektronik yang dilakukan oleh para pihak haruslah dilakukan pernyataan penerimaan secara elektronik, selain itudalam Pasal 1457-1458 Kitab Undang-Uundang Hukum Perdata dijelaskan bahwa setiap transaksi elektronik berlaku sah bagi setiap pihak yang membuatnya. Dalam hal terjadinya sengketa bisnis yang terjadi antara para pihak, guna memberikan perlindungan hukum terhadap para pihak yang bersengketa maka setiap bukti transaksi elektronik merupakan bukti yang sah sebagaimana diatur di dalam pasal 5 ayat (1), ayat (2) dan ayat (3) Undangundang No. 11 Tahun 2008 tentang Informasi dan Transaksi Elektronik.

\section{Perlindungan Hukum Bagi Para Pihak dalam E-Commerce Sebagai Akibat dari Resesi Ekonomi}

Perlindungan hukum terhadap para pihak yang melakukan kegiatan perdagangan dengan menggunakan sistem transaksi elektronik telah diatur di dalam pasal 5 ayat (1) Undang-undang No. 11 Tahun 2008 tentang Informasi dan Transaksi Elektronik, sesuai dalam pasal 5 ayat (1) UU ITE menentukan bahwa setiap dokumen elektronik atau cetakannya merupakan suatu bukti yang sah, dalam hal perlindungan hukum bagi para pihak dalam melakukan kontrak secara elektronik yang mengalami sengketa bisnis akibat dari resesi ekonomi yang melanda hampir seluruh negara di dunia saat ini, berbagai sengketa bisnis terjadi pada saat kondisi ekonomi hampir di seluruh negara di seluruh dunia saat ini mengalami resesi, berbagai sengketa bisnis tersebut diantaranya adalah berupa penipuan, pelanggaran kesepakatan yang dilakukan oleh salah satu pihak, ketidaksesuaian objek yang diterima oleh salah satu pihak, keterlambatan pembayaran yang dilakukan oleh salah satu pihak dan berbagai macam sengketa bisnis lainnya yang timbul akibat resesi ekonomi yang melanda hampir seluruh negara di dunia saat ini.

Dalam hal pengaturan perikatan bisnis di antara para pihak juga diatur di dalam Kitab Undangundang Hukum Perdata pasal 1320 dan Pasal 1457-1458 KUH Perdata, namun saat ini pemerintah dalam hal melakukan penegakan hukum pada transaksi elektronik telah diterbitkan aturan khusus yakni Undang-ndang No. 8 Tahun 2011 tentang Informasi dan Transaksi Elektronik, apabila dalam melakukan kontrak dengan menggunakan sistem transaksi elektronik terjadi penipuan yang dilakukan oleh salah satu pihak maka dalam hal ini terjadi norma konflik antara Undang-undang No. 8 Tahun 2011 tentang Informasi dan Transaksi Elektronik dengan KUHAP, Sehingga dalam memecahkan masalah norma konflik ini diberlakukan asas preferensi "Lex Specialis Derogat Legi Generalis" yaitu ketentuan atau peraturan yang sifatnya umum akan dikesampingkan oleh ketentuan yang bersifat lebih khusus, yakni dalam hal ini ketentuan yang terdapat di dalam UU No. 11 Tahun 2008 tentang Informasi dan Transaksi Elektronik lebih diutamakan daripada ketentuan yang terdapat di dalam Kitab Undang-undang Hukum Pidana yang sama-sama mengatur mengenai sanksi pertanggungjawaban pidana terhadap pelaku penipuan tersebut.

Berdasarkan hal tersebut perlindungan terhadap para pihak yang melakukan kontrak bisnis dengan menggunakan sistem transaksi elektronik mendapatkan perlindungan hukum secara preventif berupa diakuinya dokumen elektronik sebagai alat bukti yang sah sebagaimana diatur di dalam Pasal 5 Undang-undang No. 8 Tahun 2011 tentang Informasi dan Transaksi Elektronik, selain itu apabila terjadi penipuan maupun penggelapan yang dilakukan oleh salah satu pihak yang melakukan kontrak bisnis dengan menggunakan sistem transaksi elektronik mendapatkan perlindungan hukum berdasarkan pasal 45 Undang-undang No. 8 Tahun 2011 tentang Informasi dan Transaksi Elektronik.

\section{SIMPULAN DAN SARAN}

1. Simpulan

Berdasarkan hasil analisis data, dapat disimpulkan bahwa pengaturan mengenai transaksi elektronik di Indonesia secara khusus telah diatur di dalam Undang-undang Nomor 11 Tahun 2008 tentang 
Informasi dan Transaksi Elektronik khususnya di dalam Pasal 20 ayat (2) UU No.11 Tahun 2008 tentang Transaksi Elektronik, dalam pasal ini disebutkan bahwa setiap transaksi elektronik yang dilakukan oleh para pihak haruslah dilakukan pernyataan penerimaan secara elektronik. Apabila terjadi penipuan dalam kontrak bisnis maka aparat penegak hukum tetap menggunakan UndangUndang No. 8 Tahun 2011 sebagai dasar hukumnya daripada menggunakan KUHP berdasarkan asas lex specialis derogat legi generalis. Perlindungan terhadap para pihak yang melakukan kontrak bisnis dengan menggunakan sistem transaksi elektronik mendapatkan perlindungan hukum secara preventif berupa diakuinya dokumen elektronik sebagai alat bukti yang sah sebagaimana diatur di dalam Pasal 5 Undang-undang No. 8 Tahun 2011 tentang Informasi dan Transaksi Elektronik. Apabila terjadi penipuan maupun penggelapan yang dilakukan oleh salah satu pihak yang melakukan kontrak bisnis dengan menggunakan sistem transaksi elektronik mendapatkan perlindungan hukum berdasarkan pasal 45 Undang-undang No. 8 Tahun 2011 tentang Informasi dan Transaksi Elektronik untuk pembuktiannya, penegak hukum bisa menggunakan bukti elektronik atau hasil cetaknya sebagai perluasan bukti sebagaimana Pasal 5 ayat (2) UU ITE, di samping bukti konvensional lainnya sesuai dengan Kitab Undang-undang Hukum Acara Pidana.

\section{Saran}

Berkaitan dengan simpulan penelitian di atas, adapun saran yang disampaikan peneliti adalah kepada pemerintah perlumengkaji kembali peraturan Perundang-undangan terkait investasi dan perdagangan agar mengatur transaksi elektronik sebagai salah satu aturan yang akan dimuat dalam peraturan perundang-undangan tersebut, agar transaksi e-commerce memiliki dasar hukum yang jelas untuk dapat diterapkan di dunia investasi dan perdagangan di Indonesia. Kepada penegak hukum sudah saatnya untuk lebih memahami kejahatan yang terjadi dalam dunia investasi di perdagangan, karena kejahatan yang dilakukan melalui media elektronik sangatlah banyak terjadi di dalam masyarakat. Diharapkan kepada masyarakat yang menjadi korban transaksi elektronik disarankan agar tidak takut melapor atau mengadukan kepada pihak yang berwenang apabila hak - haknya dilanggar oleh pelaku usaha.

\section{DAFTAR PUSTAKA}

Azhari, A. F. (2012). Negara Hukum Indonesia: Dekolonisasi dan Rekonstruksi Tradisi. Jurnal Hukum Ius Quia Iustum, 19(4), 489-505.

Gede, A. I. D., \& Putu, B. I. N. (2018). Teori-Teori Hukum. Malang: Setra Press.

Hadjon, P. M. (1987). Perlindungan Hukum Bagi Rakyat Indonesia. PT. Bina llmu. Surabaya.

Hartono, S. (1994). Penelitian Hukum di Indonesia pada Akhir Abad ke-20. Bandung: Alumni Bandung.

Maulana, S. M., Susilo, H., \& Riyadi. (2015). Implementasi E-Commerce Sebagai Media Penjualan Online. Jurnal Administrasi Bisnis, 29(1), 1-9.

Nugroho, S. A. (2008). Proses Penyelesaian Sengketa Konsumen Ditinjau dari Hukum Aca ra serta Kehendak Implernentasinya. Kencana. Jakarta.

Putra, S. (2014). Perlindungan Hukum Terhadap Konsumen dalam Transaksi Jual-Beli Melalui ECommerce. Jurnal Ilmu Hukum, 4(2), 287-309.

Rongiyati, S. (2019). Pelindungan Konsumen dalam Transaksi Dagang Melalui Sistem Elektronik (Consumer Protection in E-Commerce). Negara Hukum, 10(1), 1-25.

Sunggono, B. S. B. (2003). Metode Penelitian Hukum Jakarta. PT Raja Grafindo Persada.

Ummah, S. R. (2017). Pornografi Ditinjau dari Hukum Positif dan Hukum Pidana Islam. Jurnal Pemikiran Dan Pembaharuan Hukum Islam, 2(2), 26-35.

Wulandari, Y. S. (2018). Perlindungan Hukum bagi Konsumen terhadap Transaksi Jual Beli ECommerce. Jurnal Ilmu Hukum, 2(2), 199-210.

Yuliana, O. Y. (2000). Penggunaan Teknologi Internet dalam Bisnis. Jurnal Akuntansi Dan Keuangan, 2(1), 36-52. 